\title{
The Effect of Personality on Motivation and Organisational Behaviour
}

\author{
Ashveen Nuckcheddy* \\ University of Northampton, UK
}

Submission: May 03, 2018; Published: May 30, 2018

*Corresponding author: Ashveen Nuckcheddy, University of Northampton, UK, Tel: +230 57864040; Email: ashveen2017@hotmail.com

\begin{abstract}
This paper performs a literature review on the topic 'the effect of personality on motivation and organisational behaviour.' The main research questions under investigation were does personality affect motivation and organisational behaviour, and does personality affect organisational behaviour. As a literature review paper, it consulted already published sources on the topic from popular journals such as Journal of Applied Psychology, Journal of Personality and Social Psychology, Journal of Research in Personality, Academy of management review, and Journal of Organizational Behaviour. The study then went ahead to perform a theoretical review of personality theories where the traits theory, the psychoanalytic, the humanistic, and the social cognitive theories were outlined. In the findings section, the review determined that personality has an influence on motivation through personal emotional stability, level of aggression, and extrovert or introvert characteristics of workers. It was also found that personality has a significant effect on organisational behaviour by influencing organisational tolerance, work environment, and work ethics. It was concluded that personality is an important topic that should be considered by management as they strive to improving motivation of workers and optimising organisational behaviour at the workplace.
\end{abstract}

Keywords: Motivation; Personality; Organisational behaviour; Management

\section{Introduction}

Personality refers to the combination of a person's characteristics that make them unique and of a distinctive character, and it forms the basis for individual differences among organizational members. There are practically no two human beings who are similar in all aspects. Barrick et al. [1] argue that even when their physical countenance may be similar, people tend to differ in their personality. One of the major concerns that the human resources office still grapples within contemporary organizations is inducing and sustaining workers' motivation. In trying to achieve this objective, it becomes relevant that they establish the relationship between personality with motivation and to what extent the former affects the latter. This paper seeks to establish this and further examine it in the context of personality and individual differences in influencing organizational behaviour at large.

\section{Research Questions}

a) How does personality influence employee motivation?

b) How does personality influence organizational behaviour?

\section{Methodology}

This paper takes the form of a literature review of pertinent studies related to personality, individual differences, and motivation. According to Wee [2], the methodology of literature review papers should at least contain the themes informing the review, databases used, keywords, and some of the major sources consulted. The themes that were found to be the most relevant were motivation, personality, and individual differences. Of most significance were those studies that attempted to link personality to motivation in an organisational setting. With respect to referencing literature sources, the Harvard system was preferred where the author-date-page format was followed in citations.

Most of the studies were sourced from journals related to management, motivation, organizational behaviour, psychology, and human resources such as Journal of Applied Psychology, Journal of Personality and Social Psychology, Journal of Research in Personality, Academy of management review, and Journal of Organizational Behaviour. Google Scholar was also sourced as a general database of some of the articles. In all cases, the primary keywords used in searching for the articles were motivation, personality, individual differences, organisational behaviour, and human resources. The timeframe allowed for the inclusion of an article was that it ought to have been written between the year 2010 and 2018. The keywords and timeframe were therefore the inclusion criteria for sources that were consulted for purposes of completing this study. 


\section{Theoretical Review}

Personality has been extensively researched and most scholars have found a strong relationship between personality and motivation of workers. Fleeson [3] consider some of the most prominent theories used in this regard to be the traits theory, psychoanalytic, humanistic, and social cognitive theories.

\section{The traits theory of personality}

This theory asserts that people exude different types of personalities based on traits that are inherently in them. Several scholars have made an attempt to explain the working of this theory. One of them is Gordon Allport, as he claims that these traits are categorized into three groups namely cardinal, central, and secondary traits Anderson [4]. Hans Eysenck also proposed another approach in line with the traits theory by categorizing people according to three scales in the determination of their personality.

Dinger et al. [5] argue that the traits theory and all its approaches are closely related to motivation at the workplace. As a human resources manager, one needs to explore the traits of their members in an organization in order to understand their personalities. According to their assessment, a good human resources manager would look into whether such a person is introvert, and that he works best when alone, instead of concluding that such a person is absolutely unproductive. In that way, Klotz [6] feel that the presence of other workers would be a demotivating factor rather than a motivating one for this worker.

\section{The psychoanalytic theory of personality}

The theory is attributed to Sigmund Freud. According to Spence [7], it asserts that one's personality is composed of three dimensions namely the id, ego, and super ego. The id is the selfish part of an individual, and it will always seek to satisfy them even at the expense of others. The super ego is the most moral and socially sensitive of one's personality as it seeks to prevent them from committing evil just because it is wrong. The ego is the mediating dimension between the aforementioned aspects. It seeks to create a compromise between the arguments of the two thereby leading to a more composed resolution. Individual differences manifest from the differences in the levels of these three dimensions of personality in a person Mc Cann [8] (Figure 1).

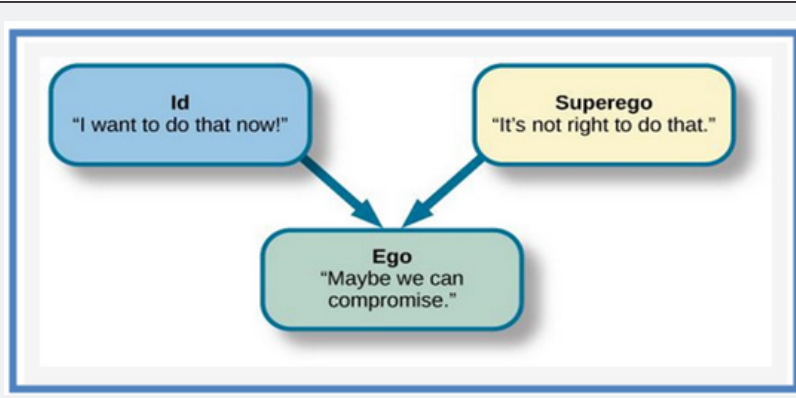

Figure 1: Lumen learning [25].

\section{The humanistic theory of personality}

This school of thought decried the issues that the former trait and psychoanalytical theories of personality failed to address. Consequently, they designed a different perspective to explain differences in personalities among people Quinney [9]. Two common scholars who are widely known for advocating for the humanistic approach of personality are Abraham Maslow and Carl Rogers. Abraham Maslow drew from his needs hierarchy theory to develop an approach towards personality. According to him, all people are guided by their need to achieve self-actualization and so is their personality. On the other hand, Carl Rogers developed an approach that he called the peoplecentred theory. In this theory, he suggests that personality is a combination of beliefs, thoughts, and feelings. He indicates that people are always aware of their self-concept. He also introduced the elements of congruence and incongruence. Congruence is when there is a match between self-concept and reality while incongruence is when there is a mismatch. This is in agreement with Quinney [9], as they state that good personalities arise when there is congruence and the opposite is true.

\section{The social cognitive theory of personality}

The social cognitive theory advocates for the fact that personality is something that one can learn from people and their environment. Walter Mischel developed this theory where he opined that people are social beings who have the ability to learn from their environment what is good and resist adopting what is deemed to be wrong. This is a departure from the former traits theory as it is against the notion that personality is in born. Mischel believes that most attributed of personality are acquired. Sherman et al. [10] particularly argue that one's personality essentially depends on the person-situation rather than trait-state (Figure 2).

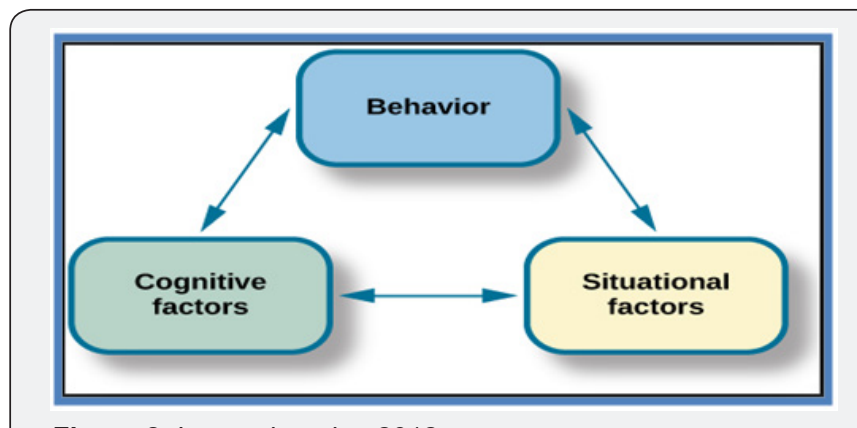

Figure 2: Lumen learning 2012.

\section{Criticism of personality theories}

Bettencourt et al. [11] have criticized trait theories for being too simplistic. Some scholars argue that even when one is said to have certain traits; it is not always that they tend to manifest. For instance, the source argues that the way someone reacts to a given stimulus today might be absolutely different from the way they react to the same stimulus in future. The psychoanalytical set of personality theories also faces the criticism that it has a 
narrow focus, seems patriarchal, and lacks a scientific basis Klotz [6]. There is no experiment that has successfully proven Freud's theory, and it therefore does not have an empirical backing for its assertions Parks-Leduc [12]. Humanistic approaches have also received a fair share of criticism mostly for the fact that they are not objective in nature, thereby rendering its findings unreliable. Finally, social cognitive theory of personality has been criticized for its findings being too preliminary, and that it fails to properly account for the relationships between social cognition, behaviour, behaviour, and personality Klotz [6].

\section{Findings}

\section{Impact of personality on motivation}

\section{Emotional stability and motivation}

Personality has been found to affect the manner in which persons are willing to be affected by motivation strategies as proposed and or implemented by management. More specifically, studies have affirmed that persons with emotional stability and those who rank low on the psychoticism are more willing to be receptive to motivation techniques Jaeggi [13]. On the other hand, persons with more aggressive personalities tend to be resistant to management even on things that are beneficial to them. For instance, when management finds that the staffs can be well motivated by inducing job rotation program, some workers may resist this viewing it as a means to allow 'outsiders' to their roles. Conway et al. [14] argue that most of such workers only appreciate monetary incentives as the sole strategy for improving their levels of motivation.

\section{Level of aggression and motivation}

With respect to Lee [15], this notion is squarely envisaged in Vroom's Expectancy theory, which suggests that the motivation of an employee and their ultimate performance is affected by personality among other factors such as experience, skills, and abilities. This notion is consistent with the research compiled by Avery [16], which opines that valence is the central tenet that comes into question whenever personality is linked with motivation. It is concerned with the emotional orientations of workers with respect to the suggested rewards, where workers with aggressive personalities will tend to be aligned to aggressive and physical rewards for them to feel motivated. Employees with less aggressive tendencies are likely to be attracted to soft and more qualitative aspects while selecting the rewards they prefer Bettencourt [11]. Emotional orientations are a direct product of people's personalities, and therefore the findings made in the studies above provide evidence of a link between personality and motivation.

\section{Extrovert and introvert effects on motivation}

Personality of workers may also be considered to be influential in how they are receptive to motivation strategies by management when such personalities are viewed as introvert and extrovert. May 2016 finds that introverts tend to respond more effectively to hygiene factors while extroverts tend to respond more effectively to the presence of actual motivators that are envisaged in the Frederick Herzberg's theory of motivation. Dinger et al. [5] are of a similar opinion where they argue that motivating introverts has very low minimal requirements as opposed to motivating persons with an extrovert personality. In fact, Avery [16] observes that extroverts are more likely to initiate civil disobedience at the workplace to show their dissatisfaction due to the presence of de-motivators. In most cases, introverts are followers and participants in strikes and demonstrations rather than being the initiators.

\section{Impact of personality on organizational behaviour}

\section{Personality effects of organisational tolerance}

Personalities and individual differences also have an effect on the conduct of an entire organization by dictating the behaviour as commonly adopted by members with regards to cultural tolerance. Barrick [1] observes that an organization with a homogenous set of personality tends to be resistant to other personalities, and, therefore less tolerant to them. Additionally, the source argues that an organization with diversity in their personalities will constantly be in conflicts in the short run. Avery [16] opines that this trend ensues because members have to learn how to co-exist with others. In the long run, members will learn to tolerate all these personalities, especially if the human resources office is working hard to iron out differences and make members accept the diversity in personalities Woehr [17].

\section{Personality and quality of work environment}

Muindi [18] finds personality has an effect on the quality of work environment. Where management fails to organize compatible personalities into departments, groups, and teams, the likely result is that conflicts will occur. Spector [19] argues that when a department is staffed with all aggressive personalities, there is very few times that consensus will be reached. On the contrary, when complimentary personalities are matched and made to work together, the outcome is constructive deliberations that rarely end in conflicts Sherman et al. [10]. Such an organization becomes a benchmark in the industry with which other organizations will be measuring their success in turning personalities and their differences into a motivating factor at the workplace. Organisational harmony is an element that ranks as among the five most critical criteria that most consider important in determining the quality of work environment. In this way, personality is affirmed to be highly influential in shaping behaviour in an organisation by having a direct impact on the quality of work environment.

\section{Personality and work ethics}

Personality also has a significant effect on the work ethics of members. Those with positive attitudes towards work are likely to be reporting to work in good time, proposing more projects, and engaging in more efficient methods of production Swider 
[20]. It is observed in Tasa et al. [21] that personal attitudes tend to also influence the success or failure of a team at work. The source notes consistently with Cogliser, Gardner et al. [22] that one of the reasons teams fail to registers success is due to the incompatible range of personalities in such teams. This acknowledgement goes a long way in hinting on the relationship between personality and organisational behaviour. Wilde [23] notes that while people with good teamwork skills are usually preferred in most cases, there is also the need to have a few persons with individuality to take on certain tasks that may be deemed not suitable for teams.

\section{Discussion}

\section{Implications of the effect of personality on motivation}

The findings section has elaborated on the effect that personality has on motivation of workers. One implication of this is that it can be used during recruitment to ensure that the workers hired can have personalities that can be effectively motivated by an organisation. As Gardner et al. [22] notes, it is for this reason that some organisations require that candidates indicate their personality types while applying or while they are being interviewed. Another implication is that is tailoring motivation strategies for the different personalities that are in an organisation. This implication is consistent with findings in Greguras \& Diefendorff [24] where it was found that matching motivation strategies to personalities helps in significantly increasing the effectiveness of those strategies.

\section{Implications of the effect of personality on organisational behaviour}

Personality was found to have a significant effect on organisational behaviour in determining the levels of tolerance, quality of work environment, and work ethics. The link between personality and tolerance can be exploited by adequately combining people with complementary personalities to the same teams where tolerance is likely to persist. Similarly, the link with work environment can be exploited by creating a sustainable environment to boost performance of workers. As Swider [20] notes, a good work environment that is tolerant of differences in personalities is one of these motivators that result in the motivation of workers at the workplace. It results in positive behaviour in the organization due to the acceptance and tolerance of diversity. Consequently, when this culture is adopted throughout the organization, it results in harmony and stability Tasa [21]. Personality was also found to have close links with work ethics, which can be useful in determining who fits to be in a department or organisation at large as a result of their perceived personality $[25,26]$.

\section{Conclusion}

As it has been seen throughout this discussion, personality has a significant effect on motivation and organisational behaviour. This information is relevant to management teams as they continuously try to provide guidance in contemporary organizations in managing crucial organizational aspects regarding motivation. By knowing and understanding how personality affect motivation of workers, management can then take a whole different approach in aligning the interests of personnel and the organization together. It is advisable that relevant bodies in organizations adopt pertinent approaches that view personnel as being of different attributes, and tailor motivation strategies that induce positive organisational behaviour. With this approach in practice, there is a high likelihood that there will be success in human resources strategies and related policies implemented by these organizations.

\section{References}

1. Barrick MR, Mount MK, Li N (2013) The theory of purposeful work behavior: The role of personality, higher-order goals, and job characteristics. Academy of management review 38(1): 132-153.

2. Wee BV, Banister D (2016) How to write a literature review paper? Transport Reviews 36(2): 278-288.

3. Fleeson W, Jayawickreme E (2015) Whole trait theory. J Res Pers 56(3): 82-92.

4. Anderson C, Hildreth JA, Howland L (2015) Is the desire for status a fundamental human motive? A review of the empirical literature. Psycholo Bull 141(3): 574-601.

5. Dinger FC, Dickhäuser O, Hilbig BE, Müller E, Steinmayr R, et al. (2015) From basic personality to motivation: Relating the HEXACO factors to achievement goals. Learning and Individual Differences 40(4): 1-8.

6. Klotz AC, Neubaum DO (2016) Research on the dark side of personality traits in entrepreneurship: observations from an organizational behavior perspective. Entrepreneurship Theory and Practice 40(1): 7-17.

7. Spence GB, Deci EL (2013) Self-determination theory within coaching contexts: Supporting motives and goals that promote optimal functioning and well-being. Beyond goals: Effective strategies for coaching and mentoring 5(11): 85-108.

8. Mc Cann CD, Higgins ET (2015) Motivation and affect in interpersonal relations: The role of personal orientations and discrepancies. Communication, Social Cognition, and Affect, Lawrence Erlbaum Associates, Hillsdale, New Jersey, USA 9(2): 53-79.

9. Quinney S, Richardson L (2014) Organisational development, appreciative inquiry and the development of Psychologically Informed Environments (PIEs). Part I: A positive psychology approach. Housing, Care and Support 17(2): 95-102.

10. Sherman RA, Rauthmann JF, Brown NA, Serfass DG, Jones AB (2015) The independent effects of personality and situations on real-time expressions of behavior and emotion. Journal of Personality and Social Psychology 109(5): 872-890.

11. Bettencourt LA, Gwinner KP, Meuter ML (2010) A comparison of attitude, personality, and knowledge predictors of service-oriented organizational citizenship behaviors. J Applied psychol 86(1): 29-41.

12. Parks-Leduc L, Feldman G, Bardi A (2015) Personality traits and personal values: A meta-analysis. Personality and Social Psychology Review 19(1): 3-29.

13. Jaeggi SM, Buschkuehl M, Shah P, Jonides J (2014) The role of individual differences in cognitive training and transfer. Memory \& cognition 42(3): 464-480.

14. Conway N, Clinton M, Sturges J, Budjanovcanin A (2015) Using selfdetermination theory to understand the relationship between calling enactment and daily well-being. Journal of Organizational Behavior 36(8): 1114-1131. 
15. Lee MT, Raschke RL (2016) Understanding employee motivation and organizational performance: Arguments for a set-theoretic approach Journal of Innovation \& Knowledge 1(3): 162-169.

16. Avery DR (2011) Support for diversity in organizations: A theoretical exploration of its origins and offshoots. Organizational Psychology Review 1(3): 239-256.

17. Woehr DJ, Arciniega LM, Poling TL (2013) Exploring the effects of value diversity on team effectiveness. Journal of Business and Psychology 28(1): 107-121.

18. Muindi FK (2011) The effect of personality on the relationship between quality of work life and job satisfaction (Doctoral dissertation). University of Nairobi (School of Business), Nairobi, Kenya.

19. Spector PE (2011) The relationship of personality to counterproductive work behavior (CWB): An integration of perspectives. Human Resource Management Review 21(4): 342-352.

20. Swider BW, Zimmerman RD (2010) Born to burnout: A meta-analytic path model of personality, job burnout, and work outcomes. Journal of Vocational Behavior 76(3): 487-506.

21. Tasa K, Sears GJ, Schat AC (2011) Personality and teamwork behavior in context: The cross-level moderating role of collective efficacy. Journal of Organizational Behavior 32(1): 65-85.
22. Gardner WL, Reithel BJ, Cogliser CC, Walumbwa FO, Foley RT (2012) Matching personality and organizational culture: Effects of recruitment strategy and the Five-Factor Model on subjective person-organization fit. Management Communication Quarterly 26(4): 585-622.

23. Wilde D (2010) Personalities into teams: we take different approaches to problems, and the best solutions are achieved by the greatest diversity. Mechanical Engineering-CIME 132(2): 22-26.

24. Greguras GJ, Diefendorff JM (2010) Why does proactive personality predict employee life satisfaction and work behaviors? A field investigation of the mediating role of the self-concordance model. Personnel Psychology 63(3): 539-560.

25. Cogliser CC, Gardner WL, Gavin MB, Broberg JC (2012) Big five personality factors and leader emergence in virtual teams: Relationships with team trustworthiness, member performance contributions, and team performance. Group \& Organization Management 37(6): 752-784.

26. Lumen Learning (2016) Psychodynamic Perspectives on Personality.

\section{Your next submission with Juniper Publishers will reach you the below assets}

- Quality Editorial service

- Swift Peer Review

- Reprints availability

- E-prints Service

- Manuscript Podcast for convenient understanding

- Global attainment for your research

- Manuscript accessibility in different formats

( Pdf, E-pub, Full Text, Audio)

- Unceasing customer service

Track the below URL for one-step submission https://juniperpublishers.com/online-submission.php 